\title{
Pollen record and paleoenvironment of a 4210 years B.P. old sediment in the Bay of Guanabara, Rio de Janeiro, Brazil
}

\author{
ORTRUD M. BARTH ${ }^{1,2,3}$, CÍNTIA F. BARRETO ${ }^{1,2}$, LUCIANE G. COELHO ${ }^{2,4,5}$ \\ and CYNTHIA F.P. LUZ ${ }^{1,2}$ \\ ${ }^{1}$ Departamento de Geologia, Instituto de Geociências, UFRJ, Ilha do Fundão, 21949-900 Rio de Janeiro, RJ, Brasil \\ ${ }^{2}$ Departamento de Botânica, Instituto de Biologia, CCS, UFRJ, Ilha do Fundão, 21949-900 Rio de Janeiro, RJ, Brasil \\ ${ }^{3}$ Departamento de Virologia, Instituto Oswaldo Cruz, Fundação Oswaldo Cruz \\ Av. Brasil 4365, 21045-900 Rio de Janeiro, RJ, Brasil \\ ${ }^{4}$ Departamento de Ecologia, Instituto de Biologia, CCS, UFRJ. Ilha do Fundão, 21949-900 Rio de Janeiro, RJ, Brasil \\ ${ }^{5}$ Escritório de Licenciamento de Petróleo e Nuclear, Instituto do Meio Ambiente, IBAMA \\ Praça 15 de Novembro 42, 20010-010 Rio de Janeiro, RJ, Brasil
}

Manuscript received on February 9, 2004; accepted for publication on May 26, 2004;

presented by NoRMA COSTA CRUZ

\begin{abstract}
Pollen analysis of a sediment sample obtained at $222 \mathrm{~cm}$ from the top of a drilling core collected in the Bay of Guanabara, Rio de Janeiro, was used as a tool to obtain more knowledge about pre-historical human living and environment. ${ }^{14} \mathrm{C}$ datation revealed the age of 4210 years B.P. Most frequent pollen grains came from plants like Alchornea (Euphorbiaceae), Celtis (Ulmaceae), Lecythidaceae, Meliaceae, Ochnaceae and spores from forest Pteridophyta. Palynology and environmental studies revealed that agricultural activities could not be detected. The dense tropical rain forest was the dominant vegetation occurring in this region.
\end{abstract}

Key words: pollen, paleoenvironment, Guanabara Bay, Rio de Janeiro, 4210 BP.

Some 500 years ago, European men established at the margins of the Bay of Guanabara, while today this area is occupied by the great cities of Rio de Janeiro and Niterói. The region around the bay was covered by a dense tropical forest, where natives maintained open some areas for habitation only and little cultivars. The actual strongly polluted bay by industrial dejects and human waste was clean and a large number of aquatic animals persisted just the great rain in 1965/66 (unpublished data).

Our investigations intend to obtain characteristics of vegetation and environment of the Guanabara Bay region long before the Europeans arrived.

A sediment sample was obtained at a distance

Correspondence to: O.M. Barth

E-mail: barth@ioc.fiocruz.br of $222 \mathrm{~cm}$ from the top of a $2.42 \mathrm{~m}$ long drilling core (T8) obtained in the Bay of Guanabara by LAGEMAR, Universidade Federal Fluminense, in a water street $2 \mathrm{~km}$ north of the island of Paquetá $\left(22^{\circ} 44^{\prime} 466^{\prime \prime} \mathrm{S}\right.$ and $\left.43^{\circ} 06^{\prime} 757^{\prime \prime} \mathrm{W}\right)$. The core was constituted mainly of siltic clay and organic material. The sample was submitted to palynological and ${ }^{14} \mathrm{C}$ analysis. Datation was executed by Beta Analytic Inc. (Miami, USA), resulting in an age of $4210+/-40$ years B.P.

The palynological analysis of the sediment showed the presence of a large variety of pollen grains, fern spores, some moos spores and organic residues. Taphonomical observations showed wellpreserved pollen grains, but severe mechanical dam- 
age due to transport, of the large spores of Pteridophyta. No oxidation effect on sporoderms was observed.

Pollen grains and spores were coming from the local vegetation of the bay borders, as well as from the regional flora through the input of sediments of a large number of rivers that flowed into the Guanabara Bay and by wind transport. As expected, pollen grains of forest tree species were the most common, followed by someone of shrubs and herbs. Alchornea (Euphorbiaceae), Celtis (Ulmaceae), Lecythidaceae, Meliaceae, Ochnaceae and spores of forest Pteridophyta had the greater representative taxa in the tropical ombrophilous forest. Pioneer plants (Cecropia, Trema) occurred also, but no pollen grains of mangroves plant species could be detected. Herbaceous and swamp vegetation was poorly represented. Taking these data in mind, the tropical forest was the dominant type of vegetation in the region at 4210 years BP. Therefore, the composition of the vegetation at this time looks different from the description of vegetation given on the coastal plain of the state of São Paulo (Ybert et al. 2003) and for the environment of younger sambaquis in the same region of study (Kneip et al. 1997).

Scientists (Amador 1997, Ireland 1987, Suguio et al. 1985) agree that at 4200 years B.P. the sea level was 1-2 m below the actual. At this time humans have mounted large layered deposits of shells and waste of bones and stones, named sambaquis (Kneip 2001, Kneip et al. 1981, 1997) in numerous places around the Bay of Guanabara (and along the Atlantic coast). Probably, they cultivated no or few crops only, as the main activities for food were hunting, fishing and mollusk capture. No significant human activities in regard to a presence of antropocoreous plant species like crops (corn, maize) and of devastated areas (Amaranthaceae, Chenopodiaceae, Asteraceae, Apiaceae) could be recognized using pollen analysis.

It may be concluded that, nevertheless, the natives inhabited the region of the Guanabara Bay at this time, then no significant environmental al- teration by the humans (like burning and agriculture) was detected. The climate was similar that today, warm and humid and the dense tropical ombrophilous forest was the home for humans and animals.

\section{ACKNOWLEDGMENTS}

We are grateful to Dr. Márcia Aguiar de Barros for valuable discussions; to Dr. José Antônio Baptista Neto, LAGEMAR, Departmento de Geologia, Universidade Federal Fluminense and to Dr. Claudia Gutterres Vilela, Departmento de Geologia, Universidade Federal do Rio de Janeiro, for core sample supply. Financial support: CNPq.

\section{RESUMO}

A análise polínica de uma amostra de sedimento obtida a $222 \mathrm{~cm}$ do topo de um testemunho coletado na baía de Guanabara, Rio de Janeiro foi realizada para obter um melhor conhecimento sobre a vida do homem pré-histórico e o meio ambiente. A datação de ${ }^{14} \mathrm{C}$ revelou a idade de 4210 anos A.P. O pólen mais freqüentemente encontrado foi de Alchornea (Euphorbiaceae), Celtis (Ulmaceae), Lecythidaceae, Meliaceae, Ochnaceae e os esporos de Pteridophyta arborescentes. Atividades agrícolas não puderam ser detectadas através dos estudos palinológicos e paleoambientais. A densa floresta pluvial tropical era o tipo de cobertura vegetal dominante na região.

Palavras-chave: pólen, paleo-meio-ambiente, Baía de Guanabara, Rio de Janeiro, 4210 AP.

\section{REFERENCES}

Amador ES. 1997. Baía de Guanabara e Ecossistemas Periféricos: Homem e Natureza. Edição do Autor, Rio de Janeiro, 539 p.

IRELAND S. 1987. The Holocene sedimentary history of the coastal lagoons of Rio de Janeiro state, Brazil. In: MJ Tooley ANd I Shennan (ed). Sea level changes. Basil Blackwell. The Institute of British Geographers Special Publications Series: 26-66. (in Muene D AND KNEIP L 1995. O sambaqui de Camboinhas e o de Maratuá e as oscilações relativas do nível do mar). 
Documento de Trabalho. Série Arqueologia, Museu Nacional, UFRJ, Rio de Janeiro, No 3: 75-82.

KNEIP L. 2001. O sambaqui de Manitiba I e outros sambaquis de Saquarema, RJ. Documento de Trabalho. Série Arqueologia, Museu Nacional, UFRJ, Rio de Janeiro, $\mathrm{N}^{\circ}$ 5, $91 \mathrm{p}$.

Kneip L, Pallestrini L and Cunha FLS. 1981. Pesquisas arqueológicas no litoral de Itaipu, Niterói, Rio de Janeiro. Rio de Janeiro: Editora Gráfica Luna Ltda., $174 \mathrm{p}$.

Kneip L, Crancio F, Santos CMC, Magalhães RMM AND Mello EMB. 1997. O sambaqui do Saco e de Madressilva - Saquarema, RJ. Documento de Trabalho. Série Arqueologia, Museu Nacional, UFRJ, Rio de Janeiro, $\mathrm{N}^{\circ} 4,67$ p.
Suguio K, Martin L, Bittencourt ACSP, Dominguez JML, Flexor JM And Azevedo AEG. 1985. Flutuações do nível relativo do mar durante o Quaternário Superior ao longo do litoral brasileiro e suas implicações na sedimentação costeira. Rev Bras Geocienc 15: 273-286.

Ybert JP, Bissa WM, Catharino ELM And Kutner M. 2003. Environmental and sea-level variations on the southeastern Brazilian coast during the Late Holocene with comments on prehistoric human occupation. Palaeogeography, Palaeoclimatology, Palaeoecology 189: 11-24. 